\title{
DISKURSUS WACANA SAINS DAN TEKNOLOGI SERTA DAMPAKNYA PADA PENDIDIKAN ISLAM
}

\author{
Andi Muhammad Asbar \\ Program Doktor Pascasarjana UIN Antasari Banjarmasin, \\ Kalimantan Selatan \\ andimuhammadasbar@gmail.com
}

\begin{abstract}
Abstrak
Wacana sains dan teknologi selalu menjadi diskursus jika diperhadapkan dengan Islam.Bahkan, kalangan sarjana berusaha mengintegrasikan dengan berbagai macam rupa. Pada kenyataannya dalam perkembangan Islam tercatat beberapa ilmuan Muslim.Salah satusumbangan terbesar Islam bagi dunia modernsaat ini,adalahmewariskan sejumlahteori pengetahuan tentang alam semesta dan cara-cara menerapkan pengetahuan tentangnya.Dalam banyakhal, hubungan antara ilmu pengetahuan (sains) dengan cara-cara menerapkannya (teknologi) telah banyak dicontohkan dan diuji cobakan oleh sejumlah sarjana muslim pada sekitar abad ke-9 M sampai13 M. Di sisi lain, integrasi Islam dengan sains dan teknologi juga menjadi wacana populer dan menjadi pemantik lahirnya kajian tentang hal tersebut di dunia akademik. Sehingga menghasilkan perjumpaan teori di antara keduanyayang pada akhirnya dapat disepakati semuanya bisa saling melengkapi dan tidak terpisahkan.Hakikat pendayagunaan teknologi adalah sebagai media pendukung aktivitas manusia. Hal tersebut harus disadari masyarakat sebagai dampak positif dari teknologi yang bersifat komplementer, serta dampaknya terhadap pendidikan Islam, maka harus mampu melahirkan manusia untuk mencapai kesuksesan di dunia dan akhirat sebagai tujuan utama pendidikan Islam. Inilah kausa-finalisnya mengapa dan untuk apa pendidikan Islam itu dalam pergolakan sosial, utamanya dalam era perkembangan IPTEK ini.Dengan kata lain pendidikan Islam harus ikut memainkan peran dan tidak sekedar menjadi penonton.Oleh karena itu, tepatlah bila pelajaran tentang IPTEK dimasukkan dalam pendidikan Islam, dan mutunya harus ditingkatkan.
\end{abstract}

Kata Kunci: Sains, Teknologi, Pendidikan Islam

\section{Pendahuluan}

$O$ alah satu pilar penyangga utama setiap masyarakat modern adalah ilmu pengetahuan dan teknologi. Peran penting yang dimainkan oleh sains modern dan penerapannya dalam bentuk teknologi di dunia modern begitu besar sehingga merupakan esensi yang absolut bagi kaum muslim tua maupun muda. Ketika berbicara soal teknologi ${ }^{1}$, yang terlihat adalah dinamika yang

${ }^{1}$ Definisi teknologi menurut Iskandar Alisyahbana (1980) adalah cara melakukan sesuatu untuk memenuhi kebutuhan manusia dengan bantuan alat dan akal, sehingga seakan-akan memperpanjang, memperkuat atau membuat lebih ampuh anggota tubuh, pancaindera dan otak manusia. Sedangkan Baiquni (1979) mengartikan teknologi sebagai hasil penerapan sistematik dari sains, yang merupakan himpunan rasionalitas insane kolektif, untuk memanfaatkan hidup dan 
berkepanjangan dalamkehidupan manusia. Telah kita lihat transformasi masyarakat tradisional yang kini menjadi masyarakat modern, hal tersebut antara lain disebabkan oleh perkembangan ilmu pengetahuan dan teknologi. ${ }^{2}$ Ledakan informasi merupakan pertanda dari peluang dan tantangan yang akan dihadapi manusia di masa depan. Pembengkakan volume informasi yang dicetuskan, dipindahkan, dan diterima akan terus dan semakin menggelembung. Seiring dengan itu, makna informasi pun meningkat pula. Pada masa itu, manusia akan hidup dalam suatu tatanan masyarakat "baru," yakni masyarakat informasi. ${ }^{3}$

Teknologi telah menyebabkan perubahan yang sangat besar dalam kehidupan manusia yang tidak pernah diperkirakan sebelumnya.Perkembangan IPTEK yang sangat pesat ini merupakan perwujudan dari makhluk tuhan dengan segenap potensi akal, indera, dan hati yang dimilikinya.Ini sejalan dengan dengan pandangan Mujamil bahwa perkembangan ilmu pengetahuan dan teknologi yang sangat luar luar biasa menakjubkan ini, boleh dikatakan adalah prestasi puncak jika diteropong dari ratusan tahun yang lalu, kendatipun masih melambung tinggi demi mencapai result yang lebih efektif dan efisien. Ratusan tahun yang lalu mungkin belum pernah terbayangkan, ternyata sekarang menjadi realita sosial yang meyakinkan. ${ }^{4}$ Diakui bahwa arus globalisasi yang melanda kehidupan umat manusia dewasa ini telah memberikan banyak hal positif dalam kehidupan umat manusia, tetapi disamping itu juga terdapat berbagai hal yang negatif. ${ }^{5}$

Dalam hal ini kita tidak dapat menyalahkan kemajuan teknologi, karena IPTEK telah menjadi tumpuan harapan manusia.Kita mengharapkan suatu bentuk kehidupan yang paling baik berkat kemajuan yang telah kita raih, namun pada gilirannya kita justru harus menanggung resiko yang makin kompleks yang mencemaskan batin kita. ${ }^{6}$ Hasil kemajuan ilmu pengetahuan dan teknologi itu ternyata hanya semata-mata karena upaya ilmiah.Sedangkan ajaran agama sebagai sumber pendidikan akhlak manusia dilupakan begitu saja. ${ }^{7}$ Itulah peta kehidupan umat manusia masa kini dan masa depan yang hanya mengandalkan kemampuan intelektualitas dan logika, tanpa memperhatikan perkembangan mental spiritual kita

mengendalikan gejala-gejala di dalam proses produktif yang ekonomis, Lihat Yusufhadi Miarso, Menyemai Benih Teknologi Pendidikan, (Jakarta: Kencana, 2005), 131.

${ }^{2}$ H.A.R. Tilaaar, Multikulturalisme: Tantangan-Tantangan Global Masa Depan dalam Transformasi Pendidikan Nasional, (Jakarta: Grasindo, 2004), 27.

${ }^{3}$ Ardoni, "Teknologi Informasi: Kesiapan Pustakawan Memanfaatkannya" Jurnal Studi Perpustkaan dan Informasi, Vol. 01 No. 02 (2005), 32.

${ }^{4}$ Mujamil, Kontribusi Islam Terhadap Peradaban Manusia, (Solo: Ramadhani, 1993), 83.

5Jalaluddin Rahmat, Psikologi Agama: Sebuah Pengantar, (Bandung: Mizan, 2004), 28.

${ }^{6}$ M. Arifin, Kapita Selekta Pendidikan (Islam dan Umum), (Jakarta: Bumi Aksara, 1991), 35.

${ }^{7}$ Munardji, Respon Pendidikan Islam terhadap Kemajuan IPTEK, dalam Mujamil Qomar, dkk., Meniti Jalan Pendidikan Islam, (Yogyakarta: Pustaka Pelajar, 2003), 184. 
terhadap sang khaliq dan nilai-nilai agama sehingga terjadi kemerosotan spiritual yang tajam.

Pendidikan Islam harus mampu mengimbangi perkembangan ilmu pengetahuan dan teknologi.Senjata perjuangan yang paling ampuh dan efektif dalam usaha menggerakkan nilai-nilai Islam dalam kehidupan ini adalah melalui pendidikan Islam baik secara teoritik maupun praktik dalam kehidupan seharihari.Oleh karena demikian konsen pembahasan artikel ini, pada dasarnya berusaha untuk menjawab beberapa masalah-masalah penting yang seringkali menjadi diskursus di kalangan sarjana maupun mahasiswa di Perguruan Tinggi. Misalnya, bagaimana perkembangan sains dan teknologi di dunia Islam, dan bagaimana integrasi Islam dengan Sains dan Teknologi serta dampak perkembangan teknologi pada pendidikan Islam. Penulis berharap, artikel ini memberikan kontribusi dalam menguraikan perkembangan sains dan teknologi di masa lalu hingga masa kekinian, yang dikaitkan dengan Pendidikan Islam.Sedangkan, metode yang digunakan adalah penelitian kepustakaan (library research), yakni dengan melalui telaah terhadap literatur/referensi dan jurnal yang relevan dengan pembahasan artikel ini.

\section{Perkembangan Sains dan Teknologi di Dunia Islam}

Salah satu sumbangan terbesar Islam bagi dunia modern sekarang, adalah mewariskan sejumlah teori pengetahuan tentang alam semesta dan cara-cara menerapkan pengetahuan tentangnya. Dalam banyakhal, hubungan antara ilmu pengetahuan (sains) dengan cara-cara menerapkannya (teknologi) telah banyak dicontohkan dan diujicobakan oleh sejumlah sarjana muslim pada sekitara badke- 9 s/d 13M. Mereka bukan hanya ditopang oleh pengetahuan dan pengalamannya, tapi juga anugerah yang melimpah denganmen dapat fasilitas dari pemerintahan, terutama pada masa-masa kejayaan Abbasiyah di Baghdad. Sebelum melahirkan teknologi, pengembangan sains lebih dahulu mereka dapatkan, bukan hanyadari hasil-hasil temuan mereka sendiri, tapi juga mereka dapatkan dari sejumlah sumber yang berasal bukan hanya dari dalam doktrin Islam saja. Kebanyakan pengetahuan tentang hukum-hukum alam, ilmu ukur dan matematika, fisika dan geometrika sampai ilmu gaya dan berat mengenai bermacam-macam benda, mereka peroleh dari warisan Yunani, Persia, India dan Mesir. Pengetahuan sainsini mereka kuasai terlebih dahulu sebelum mengembangkan teknologi. Karena ilmu-ilmu tersebut adalah sebagai dasar-dasar bagi pengembangan teknologi berikutnya. ${ }^{8}$

Beberapa contoh sains dan teknologi Islam, yang berkaitdengan warisan Hellenisme Yunani adalah filsafat, astronomi, fisika, geometrika, kimia, pertambangandan metalurgi, matematika, kedokteran, pertanian, dan sebagainya. Dalam bidang matematika kontribusi Islam telah mengenalkan system bilangan

${ }^{8}$ Lihat SeyyedHossainNasr,SainsdanPeradabanDiDalamIslam,Terj. J. Mahyudin, (PenerbitPustaka,1997),1-5. 
India, dengan mengenalkan bilangan baru nol (0) dengan sebuah titik (.). Hal ini telah mempermudah bagi proses penghitungan berikutnya, sekalipun dengan jumlah yang sangat panjang. Penulisan bilangan pertamaa dalah Muhammad bin Musa al-Khawarizm (w.875M), selanjutnya Abul Hasan al-Uqlidisy(w.953), Umar Khayyam (w.1131). Sedangkan dalam bidang astronomi pengaruh Babilonia dan India sangat terasa, apalagi sejak diterjemahkanya risalah India, Siddhanta ilmu perbintangan para raja sejak tahun711M di Baghdad. AbuMa'syaral-FalakyalBalkhy merupakan diantara tokoh yang paling terkenal dalam membuat ramalanramalan perbintangan, karyanya, Kitabal-Uluf. Bidang fisika yang paling menonjol adalah mengenai teori optic yang dikembangkan oleh Ibn al-Haitsam dalam karyanya "Kitab al-Manadzir", al-Khaziny (w.1040 M) juga mengurai tentang gaya gravitasi spesifik dalam karyanya "KitabMizanal-Hikmah". Pengobatan dalam Islam mereka dapatkan banyak dari Persiaatau Mesopotamia, India dan lainnya. Muhammad Ibn Zakariyaal-Razy (w.925M) seorang dokter dan penulis kitab pengobatan yang cukup terkenal, juga Ibn Sina dengan Qonunfi al-Thib-nya. Keduanyasama-sama telah membuktikan penguasaannya dalam hal teknologi farmasi dan kedokteran. Dan hampir menjadi sebuah kebiasaan bahwa para ahli dalam bidang farmasi dan kedokteran biasanya merangkap dalam profesinya, selain sebagai filosof dan astronom. ${ }^{9}$

George Sarton mengatakan bahwa selama periode antara $750 \mathrm{M}$ dan 1100 M, orang-orang Islam adalah pemimpin-pemimpin dunia intelektual yang tidak dapat disanggah, antara 1100 dan $1350 \mathrm{M}$, pusat-pusat belajar di dunia muslim secara global amat penting dan menarik banyak orang dari berbagai penjuru dunia. Namun, setelah $1350 \mathrm{M}$ orang-orang Eropa meulai maju sementara dunia muslim tidak saja menjadi mujud, tetapi gagal menyerap kemajuan yang dibuat di luar peradaban mereka. ${ }^{10}$ Lebih lanjut, Mehdi ${ }^{11}$ mengatakan beberapa alasan kemunduran dunia Islam, yakni: pertama, orang-orang Eropa berjuang menyikap hukum-hukum alam yang tersembunyi dan menemukan cara-cara mengeksploitasikekayaan dan sumber-sumbernya,sedangkan orang Islam menghentikan kegiatan ini dan menyerahkannya kepada orang lain. Akhirnya mereka saat ini bergantung kepada Amerika dan Eropa untuk memenuhi kebutuhan-kebutuhan elementernya; Kedua, orang Islam yang menuntut ilmu empiris kebanyakan terasing dari ilmu-ilmu agama. Akibatnya, mereka tidak memahami dunia Islam karena telah berganti dengan visi ateistik yang mendominasi tradisi keilmuan Barat;Ketiga, penghapusan studi ilmuilmu kealaman dari kurikulum madrasah agama dan kurangnya hubungan dengan sumber-sumber ilmu modern.Informasi di atas menjadi bukti bahwa, perkembangan

${ }^{9}$ SeyyedHossainNasr,SainsdanPeradabanDiDalamIslam ...,187-199.

${ }^{10}$ Mehdi Golshani, Filsafat-Sains Menurut Al-Qur'an, Terj. Agus Effendi (Bandung: Mizan, 2003), 26.

${ }^{11}$ Mehdi Golshani, Filsafat-Sains Menurut Al-Qur'an ...,27. 
teknologi di dunia Islam pernah mencapai prestasi yang gemilang.Hanya saja tidak berkelanjutan, artinya bahwa temuan-temuan sebelumnya tidak ditindaklajuti untuk dikembangan berdasarkan konteks yang sedang berlangsung kala itu.Yang pada akhirnya membawa pada kemunduran di dunia Islam.

\section{Integrasi Islam dengan Sains dan Teknologi}

Berbagai kegagalan masa lalu menyangkut relasi sains dan teknologi dan peradaban yang diakibatkan oleh berbagai benturan nilai dibaliknya, menuntut upaya lebih serius dalam melakukan pemikiran ulang terhadap teknologi (rethinking technology). Sains dan teknologi harus selalu dipertanyakan.Meskipun demikian, pertanyaan itu semestinya tidak hanya menyangkut kegunaan pragmatis teknologi (aksiologis).Akan tetapi, harus menghujam lebih dalam mempertanyakan makna (meaning) dan hakikat teknologi (essence) dalam kaitannya dengan peradaban bangsa. ${ }^{12}$ Wacana yang populer adalah integrasi agama dan sains ${ }^{13}$, hal ini menjadi topik dunia, tidak hanya dalam wilayah dunia Islam, dalam tradisi agama lain, terutama agama Kristen, sebuahmodel integrasi agama dan sains telah dikaji secara sistematis dan menghasilkanperjumpaan teori antara keduanya, sebagaimana yang dilakukan oleh tokoh ilmuan sekaligus agamawan, Ian G Barbour. Dengan sistematis ia merumuskan empat tipologi pertemuan antara agama dan sains, diantaranya konflik, independen, dialog dan integrasi. ${ }^{14}$ Seorang fisikawan terkenal dalam sejarahperkembangan ilmu pengetahuan, yakni Albert Einstein dalam Armahedi Mahzarpernah mengatakan bahwa "Religion without science is blind, science without religion is lame" pernyataan tersebut mungkin mengingatkan religiositas bagi para pelopor sains modern, seperti Copernicus, Keppler dan Newton. ${ }^{15}$

Penyataan tersebut mengingatkan bahwa agama dan sains memiliki hubungan yang sangat erat dan saling melengkapi serta tidak bisa dipisahkan.Perbedaan yang mendasar antara sains dan teknologi adalah, sains lebih banyak berbicara tentang teori dan pengetahuan mengenai macam-macam objek baik yang bersifat mendasar maupun universal, objektif dan sistematik. Sedangkan, teknolog lebih bersifat praktis, yakni ilmu tentang cara-cara menerapkan pengetahuan sains untuk memanfaatkan alam semesta bagi kesajahteraan dan kemudahan serta kenyamanan umat manusia. Keduanya sama-sama bersifat netral

\footnotetext{
${ }^{12}$ Yasraf Amir Piliang, "Budaya Teknologi di Indonesia: Kendala dan Peluang Masa Depan” Jurnal Sosioteknologi Edisi 28 (2015), 251.

${ }^{13}$ Sains diartikan dengan ilmu pengetahuan pada umumnya, ilmu pengetahuan alam, pengetahuan sistematis tentang alam dan dunia fisik, cabang dari suatu ilmu pengetahuan terutama yang diperoleh dari pengalaman, kemahiran, keahlian dan kepandaian.

${ }^{14}$ Ian G Barbour, Juru Bicara Tuhan: Antara Sains dan Agama, Terj. E. R. Muhammad, (Bandung: Mizan, 2002), 22.

${ }^{15}$ Armahedi Mahzar, Revolusi Integralisme Islam; Merumuskan Paradigma Sains dan Teknologi Islam, (Bandung: Mizan, 2004), 213.
} 
bagi kehidupan umat manusia,baik dalam hubungannya sekedar pengetahuan, maupun sebagai alat bagi kemudahan hidup mereka.

Islam tidak menentang ilmu pengetahuan dan teknologi ${ }^{16}$.Islam tidak mengenal dikotomi, memisahkan dan membedakan antara ilmu keislaman dan ilmu keduniaan.Sekalipun kebenaran yang terdapat dalam ilmu pengetahuan berupa kebenaran ilmiah (positif). ${ }^{17}$ Islam mengandung multi-disipliner ilmu pengetahuan, baik ilmu-ilmu alam (natural sciences) seperti fisika, kimia, matematika, biologi, astronomi, arkeologi dan botani.Ilmu-ilmi social (social sciences) seperti sosiologi, ekonomi, hukum, pendidikan, politik, antropologi dan sejarah.Serta humaniora seperti psikologi dan filsafat. ${ }^{18}$ Dengan demikian, berarti Islam mempunyai ajaran yang lengkap, integral dan universal.Perpaduan (integrasi) tersebut secara sederhana masing-masing dapat dilihat dalam 2 (dua) skema integrasi, yakni:

${ }^{16}$ Teknologi tidak hanya harus "dijelaskan"e berdasarkan sebuah "penjelasan ilmiah"e (explanation), tetapi lebih jauh lagi harus "ditafsirkan"e melalui sebuah cara "pemahaman"e (understanding), yaitu mencoba membentangkan maknanya yang paling dalam. Oleh karena itu, "makna"e adalah dari dan untuk manusia, pendekatan dalam "pemahaman makna"e teknologi tidak dapat lagi bersandar pada pendekatan sains dan teknologi itu sendiri, melainkan pendekatan yang berbasis pada ilmu kemanusiaan (humanity). Salah satu ilmu kemanusiaan yang mempunyai perhatian khusus terhadap makna adalah hermeneutika (hermeneutics). Hermeneutika, sebagai ilmu tentang makna "teks"e, dapat membentangkan "makna teknologie yang paling dalam, yang tidak dapat dicapai lewat pendekatan "ilmiah" semata. Lihat Yasraf Amir Piliang, "Budaya Teknologi di Indonesia..., h. 251.

${ }^{17}$ Muhammad Alim, Pendidikan Agama Islam: Upaya Pembentukan Pemikiran dan Kepribadian Muslim, (Bandung: Remaja Rosdakarya, 2006), h. 217.

${ }^{18}$ Mujamil, Kontribusi Islam Terhadap Peradaban Manusia..., h. 118. 
Skema 1: Integralisasi ilmu dalam Islam. ${ }^{19}$

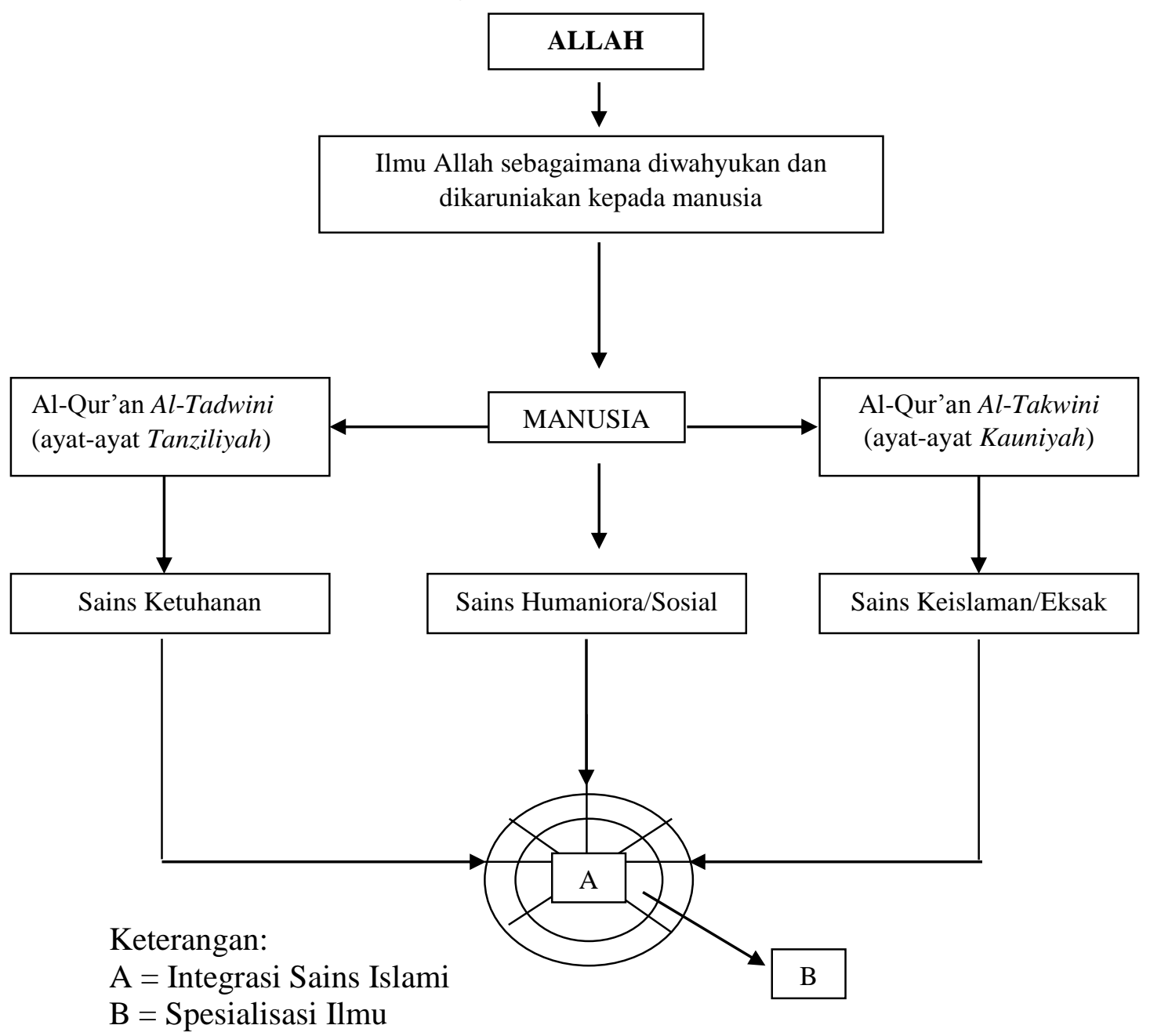

Bagan tersebut di atas, merupakan formula pemikiran kreatif untuk dapat mengintegrasikan secara padu ilmu pengetahuan dalam Islam oleh A.M. Saefuddin dan M. Zainuddin.

${ }^{19}$ Ali Maksum dan Luluk Yunan Ruhendi, Paradigma Pendidikan Universal di Era Modern dan Post-Modern: Mencari "Visi Baru” atas "Realitas Baru" Pendidikan Kita, (Yogyakarta: IrciSoD, 2004), 287. 
Skema 2: Bangunan Ilmu yang Integratif. ${ }^{20}$

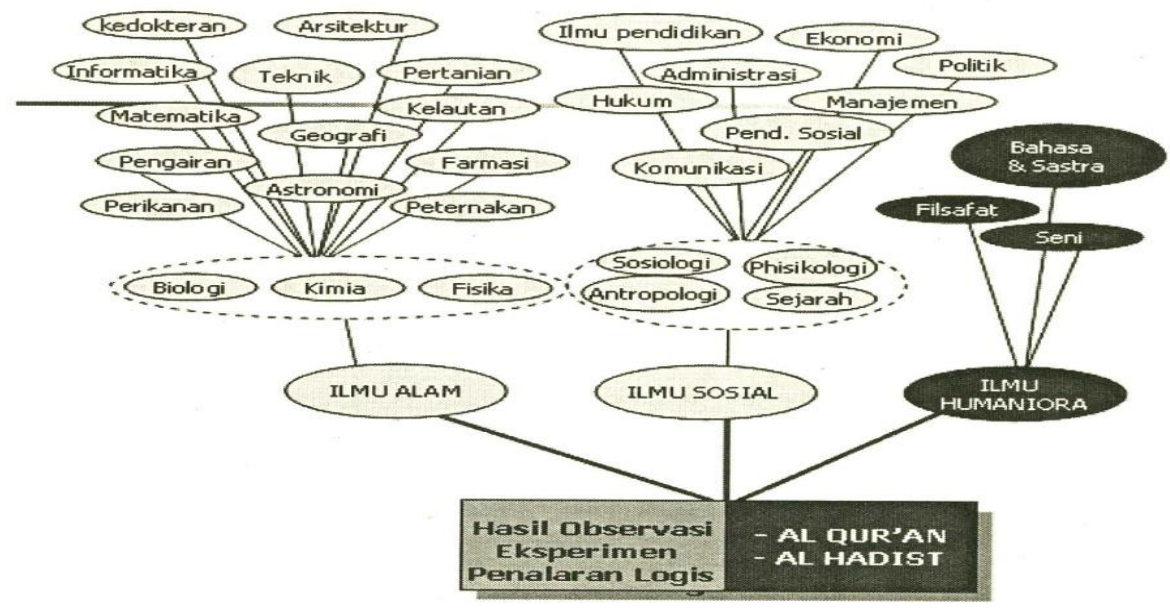

Dengan adanya penyatuan ilmu pengetahuan dengan nilai-nilai agama, dalam hal ini ajaran Islam, maka wawasan ilmu tidak lagi dipisahkan secara dikotomis dalam pembagian ilmu-ilmu agama dan non agama, tetapi akan dibedakan (bukan dipisahkan) menjadi ilmu yang menyangkut ayat-ayat qauliyah (ayat-ayat yang tersurat dalam Al-qur'an dan hadits) dan ilmu-ilmu tentang ayat kauniyah (ilmu-ilmu tentang kealaman).Berangkat dari pemikiran di atas, maka dalam pembahasan materi integrasi ini, ilmu pengetahuan yang akan diintegrasikan dengan agama (baca: Islam) adalah ilmu kealaman, ilmu sosial, dan humaniora, karena sejauh ini masih dianggap sebagai ilmu-ilmu non agama.

Berbicara mengenai agama dan ilmu pengetahuan, barangkali akan lebih spektakuler jika kita ungkapkan sabda Nabi Muhammad saw. bahwa Islam adalah ilmiyah dan amaliyah. ${ }^{21}$ Pernyataan ini mendeskripsikan suatu pemahaman bahwa Islam adalah sumber keilmiahan dan sebagai pranata ilmu pengetahuan yang harus diamalkan dalam realitas kehidupan sehari-hari.Islam merupakan pemahaman bukan sekedar informasi. Keyakinan terhadap Islam bukanlah informasi-informasi kegaiban tanpa sadar, melainkan pemikiran-pemikiran yang memiliki penunjukanpenunjukan nyata, yang dapat ditangkap akal secara langsung, selama masih berada dalam batas jangkauan akalnya.Olehnya itu, Harun Nasution menyarankan agar perasaan (filsafat dan ilmu pengetahuan tidak bisa sejalan dengan agama) itu harus dihapuskan. Sebab pandangan yang mempertentangkan antara agama dan ilmu pengetahuan itu justru akan memperlemah dinamika peradaban manusia. ${ }^{22}$ Dengan demikian ilmu dan agama berdampingan bekerjasama mengisi kehidupan dalam bidangnya masing-masing. Ilmu bidangnya dunia, sasarannya yang nyata, tugasnya

${ }^{20}$ M. Zainuddin, Paradigma Pendidikan Terpadu: Menyiapkan Generasi Ulul Albab, (Malang: UIN Malang Press, 2008), 164

${ }^{21}$ Mujamil, Kontribusi Islam Terhadap Peradaban Manusia...,117.

${ }^{22}$ Mujamil, Epistemologi Pendidikan; Dari Metode Rasional Hingga Metode Kritik, (Jakarta: Erlangga, 2007), 146. 
membina kebudayaan, agama bidangnya akhirat sasarannya yang ghaib, tugasnya membina ibadat, guna mewujudkan kehidupan keselamatan kurun waktu setelah dunia.

Berangkat dari pola pikir integratif dalam hubungannya dengan dunia pendidikan, yaitu menyatukan kehidupan dunia dan akhirat, maka pendidikan umum pada hakikatnya adalah pendidikan agama juga; begitu sebaliknya. Idealnya tak perlu terjadi persoalan ambivalensi dan dikotomik dalam orientasi pendidikan Islam.Sehingga dalam pengembangan ilmu pengetahuan dan teknologi (IPTEK), integrasi agama dan ilmu pengetahuan menjadi langkah awal bagi pendidikan Islam menuju manusia yang intelek, etis, dan bertanggung jawab, menjadi ilmuwan sekaligus agamawan di tengah-tengah masyarakat modern seperti sekarang ini. Bagaimana pun, setinggi-tinggi manusia itu berilmu haruslah tetap menundukkan keimanan hatinya kepada Allah swt.

Dalamkonteks kebudayaanIndonesia, menimbang berbagaikegagalan ideologisasi teknologidi masa lalu lewat nasionalisme teknologis, serta aspek-aspek positif paradigm yang ditawarkan Henderson ${ }^{23}$ dan Naisbitt ${ }^{24}$, dapat diusulkan di sini sebuah paradigm baru teknologi dalam konteks pembangunan peradaban Indonesia masa depan, yaitu paradigm "religiusisme teknologis" (technological religiosism).Yang dimaksud bukanlah mengatur penciptaan teknologi dengan aturan keagamaan, tetapi menggunakan "spirit" keagamaan dalam pengertian Weberian sebagai paradigma teknologi, khususnya menjadikan prinsip-prinsip dasar keagamaan: keyakinan, disiplin, konsistensi (istiqomah), haus ilmu(produktif),kritis (ijtihad), menahan diri(nafs) sebagai jalan teknologi, misalnya disiplin yang sudah mengakar pada kehidupan keberagamaan (ibadah), dapat dijadikan sebagai model disiplin dalam wacana pengembangan teknologi. ${ }^{25}$

${ }^{23}$ Henderson(1991) mengusulkan perubahanpada tingkat,,paradigma"dalam pengelolaan teknologi oleh kekuatan ekonomi. Pengelolaan teknologi selama ini didominasi oleh system kapitalisme, yang mengutamakan keuntungan ekonomi semata (economic profit) sehingga mentoleransi berbagai akses yang merusakalam, lingkungan, dan manusia sendiri. Henderson lalu mengusulkan paradigm sains dan teknologiyang lebih berpihak kepada masyarakat, yaitu paradigma teknologi yang memberikan "keuntungan sosial"(social profit) pada manusia, daripada keuntungan ekonomi semata(Henderson, 1991). Lihat Yasraf Amir Piliang, "Budaya Teknologi di Indonesia...,253.

${ }^{24}$ Naisbitt menawarkan paradigma "teknologiyang manusiawi",yaitu mengkombinasikan teknologi tinggi(high-tech) dengan sentuhan tinggi(high touch), yang disebutnyaparadigmahigh-tech high-touch.Paradigma ini menerima teknologiyang menjagakemanusiaan danmenolak teknologi yangmengancamnya. Teknologi dianggap sebagai bagian integratifevolusi kebudayaan danproduk kreatif dari imajinasi manusia. Di dalamparadigma baru ini, seni, sejarah, agama, alam, dan waktudilihat sebagaimitra setaradalam evolusi teknologi, karena semua inilah yang mampu memberikan teknologi"spirit" (Naisbitt, 1999:26).Kemajuan teknologi diharapkan sejalan dengan jalanTuhan, kepercayaan dan spiritual;senidan kemanusiaan;tidak sebaliknya, menghancurkannya. Lihat Yasraf Amir Piliang, "Budaya Teknologi di Indonesia...,253.

${ }^{25}$ Yasraf Amir Piliang, "Budaya Teknologi di Indonesia...,253. 


\section{Dampak Perkembangan Teknologi pada Pendidikan Islam}

Pengggunaan computer dimasa datang mampu mendominasi pekerjaan manusia dan mengalahkan kemampuan komputasi manusia, seperti mengontrol peralatan elektronik dari jarak jauh menggunakan media internet, IOT (InternetOf Things) memungkinkan pengguna untuk mengeloladan mengoptimalkan elektronik dan peralatan listrik yang menggunakan internet. Hal ini berspekulasi bahwa di sebagian waktu dekat komunikasi antara komputer dan peralatan elektronik mampu bertukar informasi di antara mereka sehingga mengurangi interaksi manusia. Hal ini juga akan membuat pengguna internet semangkin meningkat dengan berbagai fasilitas dan layanan internet. ${ }^{26}$ Selain itu, beberapa penelitian Internetof Things sudah banyak diterapkan dibeberapa bidang ke ilmuan dan industri, seperti dalam bidang ilmu kesehatan, informatika, geografis dan beberapa bidang ilmu lain, berikut beberapa penelitian yang sudah dilakukan. Melakukan riset tentang monitoring kesehatan pasien menggunakan wireless sensor yang dipasangkan pada tubuh pasien, beberapa hal yang dipantau adalah psikologi pasien, tekanan darah, detak jantung semua kegiatan tersebut dilakukan secara remote melalu peralatan yang terhubung ke internet dengan tetap memperhatikan kerahasiaan data pasien. ${ }^{27}$

Dalam hemat penulis, uraian di atas merupakan transformasi teknologi dan informasi dalam kehidupan manusia.Hakikat pendayagunaan teknologi adalah sebagai media pendukung aktivitas manusia.Hal tersebut harus disadari masyarakat sebagai dampak positif dari teknologi yang bersifat komplementer. Perkembangan sains dan teknologi semakin mempengaruhi kehidupan manusia. Masyarakat banyak bergantung kepada penggunaan alat-alat teknologi yangmenggunakan prinsip-prinsip sains. Disamping itu pemahaman masyarakat umum terhadap prinsip-prinsip sains adalah sangat penting dalam menjaga kesehatan dan alam sekitar, menyelesaikan masalah dalam atau dengan menggunakan alat teknologi dan dalam memberikan kesadaran tentang kebaikan dan keburukan sains dalam kehidupan. ${ }^{28}$

SitiIrene dalam Muhamad Ngafifi, mengatakan bahwa meskipun teknologimemberikan banyakmanfaatbagimanusia,namundi sisi lain kemajuan teknologimemberikan negatif padaaspeksosialbudaya, yakni, pertama, kemerosotan moral di kalangan warga masyarakat, khususnya di kalangan remajadanpelajar.Kemajuankehidupan ekonomiyang terlalu menekankan pada upaya pemenuhan berbagaike-inginan material, telah menyebabkan sebagian wargamasyarakatmenjadikaya dalam materitetapimiskin dalamrohani.Kedua, kenakalan dantindakmenyimpang di kalangan remaja semakinmeningkat

${ }^{26}$ April Juniadi, "Internet Of Things, Sejarah Teknologi dan Penerapannya: Review” Jurnal Ilmiah Teknologi Informasi Terapan, Vol. 1, No. 3 (2015), 62.

${ }^{27}$ April Juniadi, "Internet Of Things, Sejarah Teknologi dan Penerapannya...,64.

${ }^{28}$ Seth B. Sulaiman, "Pendidikan Sains, Teknologi dan Masyarakat", Jurnal Pendidikan Universiti Teknologi Malaysia Jilid 6 (2000), 66-67. 
semakinlemahnyakewibawaan tradisi-tradisiyang adadimasyarakat,seperti gotong royong dan tolong-menolong telah melemahkan kekuatan kekuatan sentripetalyang berperanpenting dalam menciptakan kesatuan sosial.Akibat lanjut bisa dilihat bersama, kenakalan dantindak menyimpangdikalangan remajadan pelajarsemakinmeningkat dalam berbagaibentuknya,sepertiperkelahian, coratcoret, pelanggaran lalu lintassampaitindak kejahatan. Dan Ketiga, pola interaksi antarmanusia yang berubah. Kehadiran computerpada kebanyakanrumah tangga golongan menengahkeatas telahmerubahpolainteraksikeluarga.Komputeryang disambungkan dengan telepon telah membuka peluang bagisiapasajauntuk berhubungandengandunia luar.ProgramInternet Relay Chatting(IRC),internet, dan e-mailtelahmembuatorangasyik dengan kehidupannyasendiri. ${ }^{29}$

Kenyataan tersebut tentu tidak bisa diingkari, kehadiran teknologi melahirkan ketergantungan teknologi.Dalam perkembangannya teknologi malah menjadi kebutuhan primer bukan lagi menjadi kebutuhan sekunder.Pernyataan tersebut tentu hal yang mengejutkan, sebab esensi penciptaan teknologi adalah menjadi instrumen pendukung aktivitas manusia untuk memperoleh kemudahan.Muhammad Tholhah Hasan mengatakan bahwa sekarang manusia mulai merasakan perlunya mengendalikan teknologi agar tidak menyimpan dari tujuannya semula, yakni memberikan kemudahan dan kesejahteraan hidup manusia, bukan merusak dan menyejahterahkannya.Manusia dituntut untuk menyadari bahwa teknologi adalah suatu konteks artifisial bagi pengaturan dan peningkatan kehidupan ekonomi, organisasi dan kemanusiaan.Masalahnya bukan menghentikan perkembangan teknologi tetapi menumbuhkan kualitas teknologi yang memungkinkan untuk meningkatkan kaum terbelakang memperoleh akses lebih besar, juga menjamin integritas ekologis dan memungkinkan manusia sebagai penguasa teknologi bukan sebaliknya. ${ }^{30}$

Dampak teknologipadaeraglobalisasi dan informasibagiperkembangan pendidikan Islam di masa depan dapat diidentifikasi, sebagaiberikut: 1) Sasaran efektif dalam penyebaran isu positifke-Islam-an yang disebabkan era intercultural dan international communication, 2) Tantangan konsep pendidikan Islam terhadap dominasi Barat dalam imperialism informasi menimbulkan sekularisme, kapitalisme, pragmatism dan sebagainya. 3) Ekspose persoalan-persoalan yang mendatangkan efekyang berbanding terbalik dengan tujuan komunikasi dan informasi tersendiri, 4) Menjaga impor teknologi komunikasi informasi daridunia Barat baik software ataupun hardware, sehingga mengadopsi nilai-nilai Islam,yang manakomunikasi dan informasi dunia Barat dipandang sebagai komoditi, bukan

${ }^{29}$ Muhamad Ngafifi, "Kemajuan Teknologi dan Pola Hidup Manusia dalam Perspektif Sosial Budaya", Jurnal Pembangunan Pendidikan: Fondasi dan Aplikasi, Vol. 2 No. 01 (2014), 44-45.

${ }^{30}$ Muhammad Tholhah Hasan, Prospek Islam dalam Menghadapi Tantangan Zaman, (Jakarta: Lantabora Press, 2005), 247-248. 
moral atau etika. Berangkat dari tantangan yang dihadapi pendidikan Islam adalah perkembangan IPTEK, maka pendidikan Islam perlu ada reorientasi secara mendalam yang di pandang dapat mengangkat perannya dalam menghadapi perkembangan IPTEK.Menurut Munardji, langkah awal yang bisa ditempuh adalah menciptakan kondisi yang memungkinkan pendidikan Islam bisa dihayati dan dipahami secara kaffah (utuh dan menyeluruh tidak ada dikotomi antar pendidikan agama dengan pendidikan umum). ${ }^{31}$

Dari pemikiran di atas, maka pendidikan Islam harus mampu melahirkan manusia untuk mencapai kesuksesan di dunia dan akhirat sebagai tujuan utama pendidikan Islam. Inilah kausa finalisnya mengapa dan untuk apa pendidikan Islam itu dalam pergolakan sosial, utamanya dalam era perkembangan IPTEK ini.M. Arifin juga menawarkan strategi pendidikan Islam dalam menghadapi tantangan modernisasi berkat kemajuan IPTEK, yaitu mencakup ruang lingkup:

1. Motivasi kreativitas anak didik ke arah pengembangan IPTEK itu sendiri di mana nilai-nilai Islami menjadi sumber acuanya.

2. Mendidik ketrampilan memanfaatkan produk IPTEK bagi kesejahteraan hidup umat manusia pada umumnya dan umat Islam pada khususnya.

3. Menciptakan jalinan yang kuat antara ajaran agama dan IPTEK, dan hubungan yang akrab dengan para ilmuan yang memegang otoritas IPTEK dalam bidang masing-masing.

4. Menambahkan sikap dan wawasan yang luas terhadap kehidupan masa depan umat manusia melalui kemampuan menginterpretasikan ajaran agama dari sumber-sumbernya yang murni dan kontekstual dengan masa kehidupan manusia. ${ }^{32}$

Penguasaan yang sama dalam bidang ilmu pengetahuan dan teknologi. Dengan kata lain pendidikan Islam ikut bermain peran dan hanya tidak bermain peran dan tidak hanya sekedar penonton oleh karena itu tepatlah bila pelajaran tentang IPTEK dimasukkan dalam pendidikan Islam, dan mutunya harus ditingkatkan. Lebih lanjut, Menurut Zulkarnain, pendidikan Islam bertujuan sebagaipengabdian dirimanusiapadapencipta alam,dengan tidakmelupakan kehidupan dunia, dengan keterbatasan pesertadidik untukmengembangkan pemahamannya, teknologi informasi menjadi solusi untuk mengakses pengetahuan sebagai bentuk pengembangan dari pemahamannya. ${ }^{33}$ Sementara itu, seiring dengan laju pesatnya gerak pembangunan, organisasi public maupun swasta semakin banyak yang mampu memanfaatkan teknologi informasi dan komunikasi yang dapat menunjang efektifitas, produktifitas, dan efisiensi mereka.

\footnotetext{
${ }^{31}$ Munardji, Respon Pendidikan Islam ..., 210.

${ }^{32}$ M. Arifin, Kapita Selekta Pendidikan...,48.

${ }^{33}$ Zulkarnain, Transformasi Nilai-nilai pendidikan Islam: Manajemen Berorientasi Link and Match, (Yogyakarta: Pustaka Pelajar, 2008), 19.
} 
Penerapan teknologi informasi dan komunikasi dalam pengembangan manajemen Pendidikan Islam agaknya dapat diidentikkan dengan penerapan teknologi informasi dan komunikasi dibidang pendidikan, yaitu dalam pembelajaran pendidikan Islam. Perkembangan ini ditandai dengan semakin pentingnya informasi dan pengelolaan data didalam banyak aspek kehidupan manusia. Dengan tersedianya berbagai bentuk media komunikasi daninformasi, kini masyarakat memiliki pilihan lebih variatif bagi informasi yang ingin mereka dapatkan. ${ }^{34}$

Dalam memanfaatkan kemajuan teknologi guna memperbaiki mutu pendidikan Islam, ada tiga hal yang harus diwujudkan, yaitu: 1) Siswa dan guru harus memiliki akses kepada teknologi digital dan internet dalam kelas, sekolah, dan lembaga pendidikan guru; 2) Harus tersedia materi yang berkualitas, bermakna, dan dukungan cultural bagi siswa dan guru, dan; 3) Guru harus memiliki pengetahuan dan ketrampilan dalam menggunakan alat-alat dan sumbersumberdigital untuk membantu siswa agar mencapai standar akademik. Sejalan dengan pesatnya perkembangan teknologi,maka telah terjadi pergeseran pandangan tentang pembelajaran baik di kelas maupun di luar kelas.Terlebih lagi perkembangan teknologi informasi telah memberikan pengaruh terhadap dunia pendidikan khususnya dalam proses pembelajaran.

\section{Penutup}

Perkembangan sains dan teknologi di dunia Islam, diyakini sebagai prototype teknologi masa kini, misalnya Penulisan bilangan pertamaa dalah Muhammadbin Musa al-Khawarizm (w.875M), selanjutnya Abul Hasan alUqlidisy (w.953),Umar Khayyam (w.1131). Sedangkan dalam bidang astronomi pengaruh Babilonia dan India sangat terasa, AbuMa'syaral-Falakyal-Balkhy merupakan diantara tokoh yang paling terkenal dalam membuat ramalan-ramalan perbintangan, karyanya, Kitabal-Uluf. Selain itu, perbedaan yang mendasar antara sains dan teknologi yaitu, sains lebih banyak berbicara tentang teori dan pengetahuan mengenai macam-macam objek baik yang bersifat mendasar maupun universal, objektif dan sistematik. Sedangkan teknologilebih bersifat praktis, yakni ilmu tentang cara-cara menerapkan pengetahuan sains untuk memanfaatkan alam semesta bagi kesajahteraan dan kemudahan serta kenyamanan umat manusia. Keduanya sama-sama bersifat netral bagi kehidupan umat manusia,baik dalam hubungannya sekedar pengetahuan, maupun sebagai alat bagi kemudahan merekahidup. Bahkan, kehadiran teknologi melahirkan ketergantungan teknologi. Dalam perkembangannya teknologi malah menjadi kebutuhan primer bukan lagi menjadi kebutuhan sekunder.Pernyataan tersebut tentu hal yang mengejutkan, sebab esensi penciptaan teknologi adalah menjadi instrumen pendukung aktivitas

19.

${ }^{34}$ Muhammad Arifin, Agama, Ilmu, dan Teknologi, (Jakarta: Golden Terayon Press, 1995), 
manusia untuk memperoleh kemudahan.Kiranya perkembangan teknologi dapat di manfaat untuk pengembangan pendidikan Islam.

\section{DAFTAR PUSTAKA}

Arifin, M. Kapita Selekta Pendidikan (Islam dan Umum), Jakarta: Bumi Aksara, 1991.

Arifin, Muhammad. Agama, Ilmu, dan Teknologi, Jakarta: Golden Terayon Press, 1995.

Alim, Muhammad. Pendidikan Agama Islam: Upaya Pembentukan Pemikiran dan Kepribadian Muslim, Bandung: Remaja Rosdakarya, 2006.

Amir Piliang, Yasraf. "Budaya Teknologi di Indonesia: Kendala dan Peluang Masa Depan" Jurnal Sosioteknologi Edisi 28 (2015).

Ardoni, "Teknologi Informasi: Kesiapan Pustakawan Memanfaatkannya" Jurnal Studi Perpustkaan dan Informasi, Vol. 01 No. 02 (2005).

Barbour, Ian G. Juru Bicara Tuhan: Antara Sins dan Agama, Terj. E. R. Muhammad, Bandung: Mizan, 2002.

Darini, Rini Sejarah Kebudayaan Indonesi Masa Hindu-Buddha, Yogyakarta: Ombak, 2013.

Golshani, Mehdi. Filsafat-Sains Menurut Al-Qur'an, Terj. Agus Effendi Bandung: Mizan, 2003.

Hasan, Muhammad Tholhah. Prospek Islam dalam Menghadapi Tantangan Zaman, Jakarta: Lantabora Press, 2005.

Juniadi, April. "Internet Of Things, Sejarah Teknologi dan Penerapannya: Review" Jurnal Ilmiah Teknologi Informasi Terapan, Vol. 1, No. 3 (2015).

Maksum, Ali dan Luluk Yunan Ruhendi, Paradigma Pendidikan Universal di Era Modern dan Post-Modern: Mencari "Visi Baru" atas "Realitas Baru" Pendidikan Kita, Yogyakarta: IrciSoD, 2004.

Mahzar, Armahedi. Revolusi Integralisme Islam; Merumuskan Paradigma Sains dan Teknologi Islam, Bandung: Mizan, 2004.

Miarso, Yusufhadi. Menyemai Benih Teknologi Pendidikan, Jakarta: Kencana, 2005.

Mujamil, Kontribusi Islam Terhadap Peradaban Manusia, Solo: Ramadhani, 1993

Mujamil, Epistemologi Pendidikan; Dari Metode Rasional Hingga Metode Kritik, Jakarta: Erlangga, 2007.

Munardji, Respon Pendidikan Islam terhadap Kemajuan IPTEK, dalam Mujamil Qomar, dkk., Meniti Jalan Pendidikan Islam, Yogyakarta: Pustaka Pelajar, 2003.

Ngafifi, Muhamad. Kemajuan Teknologi dan Pola Hidup Manusia dalam Perspektif Sosial Budaya, Jurnal Pembangunan Pendidikan: Fondasi dan Aplikasi, Vol. 2 Np. 01 (2014)

Nasr,SeyyedHossain, SainsdanPeradabanDiDalamIslam,Terj.

$\mathrm{J}$. Mahyudin,PenerbitPustaka,1997.

Poesponegoro,Marwati dan Nugroho N. Sejarah Nasional Indonesia 1, Jakarta: Balai Pustaka, 1992.

Rahmat, Jalaluddin Psikologi Agama: Sebuah Pengantar, Bandung: Mizan, 2004.

SujudPurnawanJati, Slamet. PrasejarahIndonesia:TinjauanKronologi danMorfologi, Jurnal Sejarah dan Budaya No. 2 (2013).

Sulaiman, Seth B. "Pendidikan Sains, Teknologi dan Masyarakat", Jurnal Pendidikan Universiti Teknologi Malaysia Jilid 6 (2000).

Tilaaar, H.A.R. Multikulturalisme: Tantangan-Tantangan Global Masa Depan dalam Transformasi Pendidikan Nasional, Jakarta: Grasindo, 2004. 
Tajdid: Jurnal Pemikiran Keislaman dan Kemanusiaan Vol. 3 No. 1 April 2019

Zulkarnain, Transformasi Nilai-nilai Pendidikan Islam: Manajemen Berorientasi Link and Match, Yogyakarta: Pustaka Pelajar, 2008.

Zainuddin, M. Paradigma Pendidikan Terpadu: Menyiapkan Generasi Ulul Albab, Malang: UIN Malang Press, 2008. 